African Journal of Biomedical Research, Vol. 11 (2008); 73 - 78

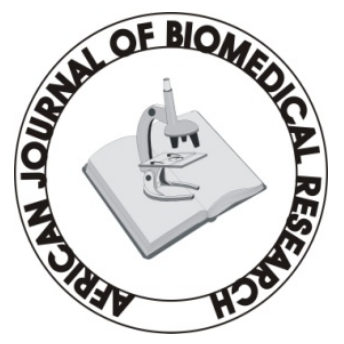

Full-text available at http://www.ajbrui.com http://www.bioline.br/md http://www.ajol.com

Received:

April 2007

Accepted (Revised):

December 2007

Published

January 2008
Full Length Research Article

\section{Total Protein and Cholesterol Concentrations in Brain Regions of Male Rabbits Fed Pawpaw Peel Meal Based Diets}

\section{BITTO I. I.}

Department of Animal Breeding and Physiology, University of Agriculture Makurdi, Nigeria

\begin{abstract}
Pawpaw parts have for long been recommended for the dry season feeding of rabbits in the tropics. Due to the deleterious effects of papain (in pawpaw parts) on some aspects of the physiology of livestock, an investigation was made of the effect of pawpaw peel meal on the total protein and cholesterol levels of the brain regions of male rabbits using 16 bucks of mixed breeds. The animals were randomly allotted in groups of 4 to 4 dietary treatments containing $0 \%$ (control), 10\%, 20\% and 30\% pawpaw peel meal. After 7 weeks of feeding, all the animals were sacrificed and the total protein and cholesterol concentrations in the brain regions evaluated. The results showed similarities $(\mathrm{P}>0.05)$ between the treatments in total protein concentrations in the cerebral cortex, medulla, hypothalamus, amygdala, mesencephalon and hippocampus. Total protein concentrations however differed significantly between diets $(\mathrm{P}<0.05)$ in the cerebellum and pons varoli with the lowest values in the diet with the highest level of pawpaw peel meal in both cases. Cholesterol levels on the other hand were significantly increased $(\mathrm{P}<0.05)$ with increasing levels of pawpaw peel meal inclusion in the cerebral cortex and mid brain but were similar between diets $(\mathrm{P}>0.05)$ in all other brain regions. The preliminary conclusion from this study is that feeding pawpaw peel meal up to a level of 30\% may suppress protein synthesis and affect the protein-lipid complexes in the brains of these animals.
\end{abstract}

(Afr. J. Biomed. Res. 11: 73 -78)

Key words: Brain regions, protein, cholesterol, bucks, tropics

*Address for Correspondence : sibittos@yahoo.com

Abstracted by:

African Index Medicus (WHO), CAB Abstracts, Index Copernicus, Global Health Abstracts, Asian Science Index, Index

Veterinarius, Bioline International , African Journals online 


\section{INTRODUCTION}

The ability of rabbits to convert forages and agro-byproducts into meat more efficiently than most other farm animals (Owen, 1981, Fielding, 1990), coupled with their short generation interval and fast growth rate (Aduku and Olukosi, 1990) gives them an advantage over other classes of livestock in the livestock economy of people in the humid tropics.

Many of the forages used in the feeding of rabbits like the Tridex species are unfortunately annual herbs. The dry season feeding of rabbits thus becomes highly dependent on crop residues and parts of some multi-purpose trees which usually survive the "bush fire" during the dry season. One of such trees is the pawpaw tree (Carica papaya Linn). Pawpaw parts have been reported to be rich in nutrients (Oyenuga, 1968; Nakasone and Paul, 1998; Egbunike et., al., 2000); and have been recommended for the feeding of rabbits, especially in the dry season (Ekpenyong, 1988; Aduku and Olukosi, 1990, Bitto and and Gemade, 2001 and Taiwo et., al., 2005).

All parts of the pawpaw tree however contain a whitish latex, rich in papain, a proteolytic enzyme. Papain has been implicated in reproductive disorders in male and female animals (Gwatin, 1964; Grag et .al. ,1970; Sigh and Devi, 1978 and Egbunike et. al. 2000). Papain-hydrolysis of pork also produced peptides that had hypochlesteroleamic effects through their interference with steroid absorption process (Morimatsu et. al., 1986). As proteins in the nervous system are known to occur in complexes with lipids and as the immediate precursors for all steroids in the body is derived from cholesterol, it becomes necessary to investigate the effect of papain containing meals on both the total protein and cholesterol concentrations of brain portions of animals fed such diets. With a dearth of such reports at present in tropical breeds of livestock generally and in rabbits in particular, this work was undertaken to provide information on the total protein and cholesterol levels in the cerebral cortex, cerebellum, medulla, hypothalamus, amygdala, pons valori, mesencephalon and hippocampus of male rabbits.

\section{MATERIALS AND METHODS}

Location: This study was conducted at a standard Rabbitary at the Department of Animal Production, University of Agriculture Makurdi Nigeria. Makurdi is located at latitude $7^{0} 14 \mathrm{~N}$ and longitude $8^{0} 21 \mathrm{E}$ with an annual rain fall ranging from $1270-1397 \mathrm{~mm}$ and a temperature range of $21^{0} \mathrm{C}-42^{0} \mathrm{C}$.

Animals and Management: 16 grower rabbits of mixed breeds (Chinchilla x California x New Zealand White) between the ages of 9 and 11 weeks with a mean initial weight of $1,200 \mathrm{~g}$ were used for this study. They were housed in individual cages measuring $1.5 \mathrm{~m} \times 1 \mathrm{~m} \times 1 \mathrm{~m}$ with corrugated roofing sheets and wire mesh floor with wooden frames. They were fed a maize based concentrate diet for a week of acclimatization with cool clean drinking water always before the commencement of experimental feeding.

Pawpaw Peels: Unripe pawpaw fruits were obtained from Gboko, Otukpo and Makurdi towns in Benue State Nigeria. The peels were carefully removed from the pulp immediately after harvest and sun dried for 7 consecutive rain free days and there after ground for incorporation into the test diets as pawpaw peel meal (PPM).

Experimental Diets: 4 isocaloric and isonitrogeneous diets were compounded with diet 1 (control) containing no PPM while diets 2, 3, and 4 contained 10\%, 20\% and 30\% PPM respectively. A completely randomized design was used to assign the animals to the experimental diets such that there were 4 bucks on each diet. The animals were fed the diets ad libitum with cool clean drinking water supplied always. The bucks were weighed individually weekly. The 
proximate compositions of the experimental diets were determined by the A.O.A.C (1990) method. The bucks were fed the test diets for 7 weeks.

Sampling: After 7 weeks of feeding, all the bucks were starved for 12 hours and there after sacrificed by stunning and decapitation. The heads were severed at the occipito atlantal joint and immediately placed in ice containers for proper labeling. All the heads were then frozen at $-20^{\circ} \mathrm{C}$ for two weeks before dissection. During dissection, each head was placed in a dorsoventral position for cutting before the brain was carefully dug out by blunt dissection. The brain was then freed of adhering meaninges, weighed and dissected out as described by Egbunike (1981). Samples of each brain region were then weighed using a sensitive digital balance and homogenized in $1 \%(\mathrm{w} / \mathrm{v}) 0.1 \mathrm{M}$ ice cold buffer.

The total protein and cholesterol concentrations in brain regions were evaluated as outlined by the Boehringer Mannheim Diagnostica (1979) as already reported (Bitto et. al., 2000).
Statistical Analysis: Data were subjected to the one way analysis of variance (ANOVA) using the completely randomized design, while the Least Significant Difference (LSD) was used to assess the differences between means. All statistical analyses were by methods outlined by (Steel and Torrie, 1980).

\section{RESULTS AND DISCUSSION}

Tables 1 and 2 show the gross and chemical compositions of the test diets while the effects of the test diets on the concentrations of total protein and cholesterol in brain regions are presented in Tables 3 and 4 respectively.

There were similarities $(\mathrm{P}>0.05)$ between the diets in the concentration of total protein in the cerebral cortex, medulla, hypothalamus, amygdala, mesencephalon and hippocampus. Total protein concentration in the highest level of PPM inclusion (30\%) was however significantly decreased $(\mathrm{P}<0.05)$ in the cerebellum. A more pronounced effect of diet on total protein concentration was obtained in the pons where the control diet was superior $(\mathrm{P}<0.05)$ to all the PPM diets.

Table 1:

Composition of the Experimental Diets (\%)

\begin{tabular}{|c|c|c|c|c|c|c|}
\hline Ingredients & $1(0 \%)$ & $2(10 \%)$ & $3(20 \%)$ & & $4(30 \%)$ & \\
\hline Maize & 30.16 & 33.39 & & 37.66 & & 41.43 \\
\hline Soyabean meal & 28.12 & 22.67 & & 17.19 & 11.81 & \\
\hline Rice offals & 35.32 & 27.54 & & 18.75 & & 10.36 \\
\hline Pawpaw peels & - & 10 & & 20 & & 30 \\
\hline Vitamin premix & 0.5 & 0.5 & & 0.5 & & 0.5 \\
\hline Palm oil & 1 & 1 & 1 & & 1 & \\
\hline Bone meal & 4 & 4 & 4 & & 4 & \\
\hline Methionine & 0.4 & 0.4 & 0.4 & & 0.4 & \\
\hline Salt & 0.5 & 0.5 & 0.5 & & 0.5 & \\
\hline Total & 100.00 & 100.00 & 100.00 & & 100.00 & \\
\hline
\end{tabular}


Table 2:

The Chemical Compositions of the Experimental Diets (\%)

\begin{tabular}{|c|c|c|c|c|}
\hline Parameters & $1(0 \%)$ & $2(10 \%)$ & $3(20 \%)$ & $4(30 \%)$ \\
\hline Dry matter & 98.50 & 97.98 & 97.87 & 97.87 \\
\hline Ether extract & 11.20 & 12.67 & 10.47 & 11.71 \\
\hline Crude fibre & 19.40 & 17.69 & 15.18 & 12.94 \\
\hline Crude protein & 20.25 & 20.94 & 18.38 & 17.44 \\
\hline Ash & 13.82 & 12.91 & 11.70 & 11.68 \\
\hline M.E (Kcal/kg)* & 2850.46 & 2992.60 & 3012.40 & 3041.66 \\
\hline
\end{tabular}

$* \quad=\quad$ Calculated from Pauzenga (1985).

Table 3:

The effect of pawpaw peel meal on the total protein concentration of brain regions of male rabbits (mean \pm SEM.)*

\begin{tabular}{lcccc}
\hline \multicolumn{1}{c}{ Brain regions } & \multicolumn{3}{c}{ Diets } \\
\hline \multicolumn{1}{c}{$1(0 \%)$} & $2(10 \%)$ & $3(20 \%)$ & $4(30 \%)$ \\
\hline Cerebral cortex & $0.81 \pm 0.27$ & $1.00 \pm 0.15$ & $0.80 \pm 0.19$ & $0.99 \pm 0.10$ \\
\hline Celebellum & $0.95 \pm 0.34^{\mathrm{a}}$ & $1.14 \pm .25^{\mathrm{a}}$ & $0.95 \pm 0.24^{\mathrm{a}}$ & $0.47 \pm 0.05^{\mathrm{b}}$ \\
\hline Medulla Oblongata & $0.66 \pm 0.14$ & $0.76 \pm 0.16$ & $0.63 \pm 0.13$ & $0.76 \pm 0.17$ \\
\hline Hypothalamus & $0.95 \pm 0.24$ & $0.76 \pm 0.20$ & $0.90 \pm 0.25$ & $0.85 \pm 0.22$ \\
\hline Amygdala & $1.00 \pm 0.24$ & $1.01 \pm 0.18$ & $1.07 \pm 025$ & $0.95 \pm 0.11$ \\
\hline Pons & $1.26 \pm 0.12^{\mathrm{a}}$ & $0.82 \pm 0.23^{\mathrm{b}}$ & $0.87 \pm 0.14^{\mathrm{b}}$ & $0.67 \pm 0.13^{\mathrm{b}}$ \\
\hline Mesencephalon & $0.73 \pm 0.24$ & $0.80 \pm 0.10$ & $0.69 \pm 0.05$ & $0.63 \pm 0.07$ \\
\hline Hippocampus & $1.24 \pm 0.20$ & $1.19 \pm 0.14$ & $0.99 \pm 18$ & $0.95 \pm 0.21$ \\
\hline
\end{tabular}

$*=$ values are expressed in $\mathrm{g} / 100 \mathrm{ml} ; \mathrm{SEM}=$ standard error of mean.

$a, b=\quad$ values in the same row bearing different superscripts are significantly different $(P<0.05)$.

Table 4:

The effect of pawpaw peel meal on the cholesterol concentration of brain regions of male rabbits (means \pm sem).

Brain regions Diets

\begin{tabular}{|c|c|c|c|c|}
\hline & $1(0 \%)$ & $2(10 \%)$ & $3(20 \%)$ & $4(30 \%)$ \\
\hline Cerebral cortex & $216.15^{\mathrm{a}} \pm 7.10$ & $237.50^{\mathrm{b}} \pm 9.45$ & $233.08^{b} \pm 6.60$ & $304.00^{\mathrm{C}} \pm 8.50$ \\
\hline Cerebellum & $233.69 \pm 5.25$ & $230.00 \pm 5.00$ & $241.41 \pm 7.34$ & $239.50 \pm 6.74$ \\
\hline Medulla oblangata & $297.20 \pm 8.65$ & $288.60 \pm 4.31$ & $286.44 \pm 3.12$ & $291.35 \pm 7.00$ \\
\hline Hypothalamus & $180.29 \pm 9.60$ & $177.35 \pm 4.15$ & $182.47 \pm 6.80$ & $179.52 \pm 5.50$ \\
\hline Amygdala & $281.73 \pm 4.70$ & $290.85 \pm 4.70$ & $286.60 \pm 8.30$ & $290.45 \pm 6.30$ \\
\hline Pons & $248.90 \pm 7.00$ & $244.16 \pm 5.55$ & $251.30 \pm 8.10$ & $247.50 \pm 6.80$ \\
\hline Mesencephalon & $126.00 \pm 4.20^{\mathrm{a}}$ & $146.50 \pm 3.75^{b}$ & $141.43 \pm 7.00^{b}$ & $162.90 \pm 3.85^{\mathrm{c}}$ \\
\hline Hippocampus & $148.60 \pm 9.64$ & $148.15 \pm 8.00$ & $152.29 \pm 5.00$ & $157.80 \pm 4.65$ \\
\hline
\end{tabular}


The significantly lower concentration of total protein in the cerebellum of animals on the diet with the highest level of PPM may be an indication of the interference of residual papain in PPM (at such a high level of inclusion) with neural mechanisms involved with protein synthesis and the rate of turn over in the cerebellum. Being that the cerebellum functions as a coordinator of the brain's other processes (including neurosecretions) more work is required to elucidate the mechanism of action of papain in this regard. The significant difference between the control diet and the PPM based diets in the total protein concentration in the pons further confirms the possibility of the interference of papain with protein synthesis in some brain centers. Going by the results obtained in this study, it does appear that the pons was more sensitive to papain than the cerebellum which in term was more sensitive than other brain regions.

Total protein levels in the brain regions in the present study were generally higher than values reported in the brain regions of pigs by Adejumo and Egbunike (2001). This disparity may be due to species differences in biochemical characteristics of brain regions.

Cholesterol concentrations were similar $(\mathrm{P}>0.05)$ between diets in all brain regions except in the cerebral cortex and mesencephalon where the control diet was in both cases significantly lower in value $(\mathrm{P}<0.05)$ than the PPM based diets.The diet with the highest level of PPM (30\%) had a significantly higher $(\mathrm{P}<0.05)$ level of cholesterol than the other diets. These results suggest that cholesterol being involved in several cellular actions including the formation of cohesive membranes as a protection against shock and stress (Poulos et. al., 1973) may have been synthesized in higher amounts to protect sensory receptors in these regions. Further work is again needed to elucidate the involvement of papain with cholesterol levels in the brains of rabbits.

\section{Conclusion:}

This study demonstrates that the inclusion of pawpaw peel meal up to $30 \%$ in the diet of bucks may suppress protein synthesis and affect protein lipid complexes in some brain regions which may eventually alter the biochemistry of the nervous system probably with adverse effects on the animals.

\section{REFERENCES}

Adejumo, D.O. and Egbunike, G. N. (2001). Effect of prepubertal, pubertal and postpubertal orchidectomy and testosterone therapy on the acetylcholinesterase activity and protein content in the brain and hypophyses of pigs. Trop. Anim. Prod. Invest. 4:157-165.

A.O.A.C. (1990). Official methods of analysis of the Association of Official Analytical Chemists (15 ${ }^{\text {th }}$ ed), Washington.

Aduku, A. O. and Olukosi, J. O. (1990). Rabbit management in the Tropics. Living Books Series. GU Publications, Abuja, Nigeria.

Bitto, I.I.; Akusu; M.O.; Egbunike, G.N. and Akpokoje, J.U. (2000) .A comparative study of spermatozoal abnormalities and some biochemical characteristics of ovine and caprine semen in the humid tropics. Trop. J. Anim. Sci. 3 (1): 169-174.

Bitto, I. I. And Gemade, M. (2001). Preliminary investigations on the effect of Pawpaw peel meal on growth, visceral organ andendocrine gland weights, testicular morphometry and the haematology of male rabbits. Global J. P. \& Appl. Sci. 7(4): 611-625.

Boehringer Mannheim Diagnostic Assays' Manual, (1979). Boehringer Mannheim $\mathrm{CmBH}$ (Germany) Diagnostica.

Egbunike, G. N.; Sadiku, M. O. and Okebiorun O. E. (2000). Sperm production and related phenomenon in rats fed diets containing pawpaw peels seed and leaves. Trop. J. Anim. Sci. 3(2). 77-84.

Ekpenyong, T. E. (1988). Growth performance and breeding standards for rabbits. A paper presented at the National production seminar organized by A.E.R.L.S., A.B.U. Zaria, PP 1-24. Egbunike, G.N. (1981) Regional distribution of acetylcholinesterase activity in the brain and hypophyses of crossbred European boars reared in the humid tropics. Acta anat. 110:248-252. 
Grag, S. K.; Saksena, S. K. and Chaudhury, R. R. (1970). Antifertility screening of plant parts. VI. Effect of five indigenous plants on early pregnancy in albino rats. Indian J.Med. Res. 58: 1258.

Gwatkin, R. B. L. 1964. Effects of enzymes and acidity on the zona pellucida of the mouse egg before and after fertilization J. Reprod. Fert. 7:99.

Nakasone, H. Y. and Paul, R. E. (1998). Tropical fruits. Biddled LTD. Guild Ford and Kings. PP 239-268.

Owen , J.K. (1981) Rabbit meat for developing countries. World Anim. Res. $39: 2-11$.

Oyenuga, V. A. (1968): Nigeria's foods and feeding stuff: their chemistry and nutritive value. University of Ibadan press, Ibadan.
Poulos, A.; Voglmayr, J. K. and I. G. White (1973) Phospholipid changes in spermatozoa during passage through the genital tract of the bull. Biochim. Biophy. Acta. 306:194-202.

Singh, S. and Devi, S. (1980) Effect of papain on foetal chodrogenesis; Result male of material administration of the enzyme in the rat. Indian J. Exp. Biol. 18: 953-957.

Steel R. G. D and Torrie, J.O.H. (1980). Principles and procedures of statistics: A Biometrical approach $2^{\text {nd }}$ Ed. Mc Graw - Hill Book Co. Inc. New York

Taiwo, A. A.; Adejuyigbe, A. D.; Adebowale, E. A.; Oshotan, J. S. and David, O. O. (2005). Performance and nutrient digestibility of weaned rabbits fed forages supplemented with concentrate. Nig. J. Anim. Prod. 32(1): 74-78. 